\title{
EFFECT OF ROOT OF VETIVER GRASS AND THE SHEAR STRENGTH OF ROOT IN PERMEATED SOIL
}

\author{
${ }^{1}$ Jared, N.S., ${ }^{2}$ Noorasyikin, M.N* \\ ${ }^{1}$ Faculty of Engineering, Built Environment and Information Technology, SEGi University, \\ 57810 Petaling Jaya, Selangor, Malaysia. \\ ${ }^{2}$ Faculty of Civil Engineering and Built Environment, Universiti Tun Hussein Onn Malaysia, \\ 86400 Batu Pahat, Johor, Malaysia. \\ * Corresponding Author: norasyikin@uthm.edu.my TEL: (+60)16-8312076
}

\begin{abstract}
Recently, bioengineering has been approached as one of the slope stabilizations techniques as it is inexpensive compared to the mechanical stabilization technique. However, numbers of slope failure still reoccur due to the limitation of the bioengineering technique knowledge. Proper bioengineering material and methods must be carefully selected to overcome the problem. The objectives of this research are to determine the physical and mechanical properties of soil with Vetiver Grass roots as well as the root properties of the Vetiver Grass since these grass types have been applied widely for slope stabilization. The physical properties of soil lab tests have been determined such as compaction test, Atterberg limits test and sieve analysis test. The mechanical properties of soil with and without root grasses have been carried out through the shear box test. For the identification of the root properties of Vetiver Grass, the root morphology and the diameter of the root has been identified. The results for the lab tests conducted showed that the soil with roots have a higher shear strength compared to soil without roots included with FOS (Factor of Safety) calculation proving that the soil with the aid of Vetiver Grass will be effective in retaining soil.
\end{abstract}

Keywords: Slope Failure, Root Properties, Factor of Safety (FOS), Root Strength 


\section{Introduction}

Man-made disturbances such as roadside or reclamation projects are factors which cause major soil erosion problems (Acharya et al., 2016). It tends to destroy the soil profile of the nearby soil and adversely affects the surrounding natural habitat. During these instances temporary cover crops are a popular strategy as it aids the restoration efforts by establishing a nutritional base necessary for re-vegetation and it also offers a natural soil-root matrix which anchors naturalizing plants (Singh, A.K,2010., Chirico, G.B et al.,2013 \& Acharya et al., 2016).

Engineers choose the use of vetiver grass and other types of grasses for means of slope stabilization because of three main factors. Firstly, the price is competitive so most people would be able to afford the use of the grass (Kacimov \& Brown, 2015). Secondly it is simple which also adds to the market of people who can use it, and it does not require heavy machinery to operate (Khalilnejad et al., 2012).

\subsection{Slope Failure}

Slope failure is a major risk factor to the surrounding environment and is caused by the heavy increase in pore water pressure due to a heavy downpour of rain (Lee \& Hewitt, 1982). There are many types of slope failure which are, transitional slide, rotational slide, flow slide, wedge slide. In general, slope failure is caused, by natural forces, burrowing animals and human misjudgment (Lee \& Hewitt, 1982). Some causes of slope failures are seen as follows: erosion, rainfall, earthquakes, geological features, external loading, construction activities, rapid drawdown. In the process of obtaining soil stability there are few bioengineering techniques which can be used to complement the slope. Some of which include Brush-Mattress, Wattle Fences, Log Brush and Fascines. A lot of situations prevail when vegetation is used in order to aid slope stability (Meunchang et al., 2004). What is needed is the role of vegetation on a slope which is made of soil. A slope without any aid of any kinds is prone to slope failure. Many regions of the world are exposed to the slope failure and the effect that come with it; some include shallow landslides on steep slopes. These slopes often contain well drained, poorly cohesive soils covered by dense forests. The stability of these slopes highly depends on the mechanical reinforcement provided by the plant roots of the forest to the soil which makes the soil less saturated and increases its resistance (Meunchang et al., 2004). Assessing the stability enhancement due to vegetation on the slope is an 
important aspect for a reliable assessment of the spatial and temporary distribution of these shallow landslide hazards.

\section{Methodology}

All the experiments were conducted in SEGi University Concrete lab according to the relevant standard. The experiment conducted for physical determination are as follows: Compaction test, Atterberg Limits Test and Sieve Analysis test. The shear box test was conducted to identify the mechanical properties of the soil. For the determination of the root diameter and root length, the vernier caliper was applied while root morphology was observed by naked eyes.

\section{Results \& Discussion}

\subsection{Sieve Analysis Test}

The standard used for this test is following the ASTM D 422 - Standard Test Method for Particle Size Analysis of Soil. The sieve analysis test was conducted in accordance to the stated procedure. This test is conducted to determine the size of soil particles by passing the soil through various sieves. From the results can determine the type of soil if it is gravel, sand, silt, or clay. Below are the results for the laboratory experiment for the sample obtained. Table 1 shows the summary of sieve analysis results.

Table 1. Summary of sieve analysis results

\begin{tabular}{|c|c|c|c|c|c|c|c|}
\hline Place & $\begin{array}{c}\text { Location } \\
(\mathbf{K M})\end{array}$ & $\begin{array}{c}\text { Gravel } \\
(\boldsymbol{\%})\end{array}$ & $\begin{array}{c}\text { Sand } \\
(\boldsymbol{\%})\end{array}$ & $\begin{array}{c}\text { Fine Sand } \\
(\boldsymbol{\%})\end{array}$ & $\mathbf{C u}$ & $\mathbf{C g}$ & $\begin{array}{c}\text { Soil } \\
\text { Classification }\end{array}$ \\
\hline Karak & 152.3 & 21.59 & 69.11 & 9.3 & 9.39 & 0.12 & $\begin{array}{c}\text { Poorly } \\
\text { Graded Sand }\end{array}$ \\
\hline Temerloh & 161.2 & 13.24 & 61.65 & 25.11 & 5.52 & 0.1 & $\begin{array}{c}\text { Poorly } \\
\text { Graded Sand }\end{array}$ \\
\hline Kuantan & 189.2 & 7.86 & 88.37 & 3.77 & 5.1 & 0.158 & $\begin{array}{c}\text { Poorly } \\
\text { Graded Sand }\end{array}$ \\
\hline
\end{tabular}


To ensure the accuracy of the result the same amount of soil was used for each sieve analysis from the three locations. A $1000 \mathrm{~g}$ dried sample was used from each sample soil from the three locations and put through the sieve shaker passing the particles through different sieve sizes. The largest sieve diameter that was used in this experiment was a $3.35 \mathrm{~mm}$ sieve and the smallest diameter of sieve used in this experiment was a $0.045 \mathrm{~mm}$ sieve. From prior knowledge in soil mechanics the soil retained in the larger diameter sieve is known as a gravel, and the soil which has passed through the smallest sieve is known as the very fine sand particles. Also, the soil which is retained in the middle is known as sand. Soil samples can be differentiated when more than $50 \%$ of soil is seen on either the smallest sieve diameter or on the highest diameter sieve being used. With these findings, it is confirmed that the classification of all the soil samples collected are following the classification of "Poorly Graded Soil".

\subsection{Compaction Test}

This compaction test was done in accordance to ASTM D 608 - Standard Test Method for Laboratory Compaction Characteristic of Soil Using Standard Effort. From the compaction graph, Table 2 can be constructed. Table 2 shows the result of the maximum dry unit weight of the test, the optimum water content from the location samples from Karak, Temerloh and Kuantan.

Table 2. Summary of compaction test results

\begin{tabular}{|c|c|c|c|}
\hline Place & Location $(\mathbf{K M})$ & $\begin{array}{c}\text { Maximum Dry Unit } \\
\text { Weight }(\mathbf{k N} / \mathbf{m 3})\end{array}$ & $\begin{array}{c}\text { Optimum Moisture } \\
\text { Content }(\boldsymbol{\%})\end{array}$ \\
\hline Karak & 152.3 & 21.01 & 13.73 \\
\hline Temerloh & 161.2 & 20.11 & 14.32 \\
\hline Kuantan & 189.2 & 26.33 & 12.52 \\
\hline
\end{tabular}

The primary objective of conducting the compaction test was to identify the Optimum Moisture content of the soil and also to find out the Maximum Dry Unit Weight of the soil from the locations where the soil was taken from being, Karak, Temerloh and Kuantan. From prior soil mechanics knowledge know that the higher the dry unit weight of the soil, the stronger the soil, while when the dry unit weight of the soil is low, we can identify that the soil is weak. The OWC Optimum water content of the soil is a major factor in the soil having a high overall strength. But need to take into consideration that this only applies to coarse grained soils more effectively than compared to that of a soil with fine grains. Water that fills up the air voids in the soil will reduce the friction 
between the soil particles and in turn decrease the strength of the soil. This is why the OWC optimum water content must be found so that can get the right amount of water to be put into soil without decreasing the strength of the soil.

\subsection{Atterberg Limits Test}

The Atterberg Limits Test for this research was performed in the concrete laboratory of SEGi University, Kota Damansara according to the ASTM D 4318 - Standard Test Method for Liquid Limit, Plastic Limit and Plasticity Index of soils. The Plasticity Index of the soil measures the plasticity of the soil and the data for that is shown in the Table $\mathbf{3}$ for all the samples.

Table 3. Summary of Atterberg Limit Test

\begin{tabular}{|c|c|c|c|c|}
\hline Place & Location $\mathbf{( k m )}$ & $\begin{array}{c}\text { Liquid Limit } \\
\mathbf{( \% )}\end{array}$ & $\begin{array}{c}\text { Plastic Limit } \\
\mathbf{( \% )}\end{array}$ & $\begin{array}{c}\text { Plasticity } \\
\text { Index }(\boldsymbol{\%})\end{array}$ \\
\hline Karak & 152.3 & 14.9 & 13.6 & 1.3 \\
\hline Temerloh & 161.2 & 19.1 & 20.3 & 1.2 \\
\hline Kuantan & 189.2 & 24.2 & 23.43 & 0.77 \\
\hline
\end{tabular}

The Plasticity Index (PI) may be calculated using the data from the Liquid Limit (LL) and the Plastic Limit (PL). The Plasticity Index (PI) was calculated by using Equation 1:

$$
\mathrm{PI}=\mathrm{LL}-\mathrm{PL}
$$

The results show the sandy soil contains low clay content with LL and PL values ranged from 13.6 to $24.2 \%$. Based on PI values which are ranged from 0.77 to 1.3 , the soil can be classified as sandy soil with slight plasticity and less compressibility. The shape and volume of soil itself cannot be altered.

\subsection{Root Properties of Grass}

The roots morphologies of Vetiver Grass were identified as Fibrous root system shown in Figure 1. The diameters and the length of primary and secondary grass roots from the grass samples collected were measured and recorded according to Table 4. The manual Vernier calipers was used 
to measure the dimensions of the roots shown in Figure 2. The measurements were taken at 10 fibers of grass roots.

Table 4. Root dimensions for the vetiver grass

\begin{tabular}{|c|c|c|c|}
\hline \multirow{2}{*}{$\begin{array}{c}\text { Grass } \\
\text { Sample }\end{array}$} & \multicolumn{3}{|c|}{ Vetiver Grass } \\
\hline & & & \\
\hline & Fibrous Root & & \\
\hline & \multicolumn{3}{|c|}{ Figure 1. Root sample } \\
\hline & \multicolumn{2}{|c|}{ Root Diameter (mm) } & \multirow[t]{2}{*}{ Length $(\mathrm{cm})$} \\
\hline & Primary & Secondary & \\
\hline 1 & 0.75 & 0.52 & 25 \\
\hline 2 & 0.78 & 0.51 & 20 \\
\hline 3 & 0.74 & 0.53 & 15 \\
\hline 4 & 0.73 & 0.54 & 30 \\
\hline 5 & 0.70 & 0.58 & 33 \\
\hline 6 & 0.71 & 0.54 & 25 \\
\hline 7 & 0.73 & 0.53 & 18 \\
\hline 8 & 0.79 & 0.53 & 30 \\
\hline 9 & 0.75 & 0.52 & 31 \\
\hline 10 & 0.72 & 0.51 & 28 \\
\hline
\end{tabular}

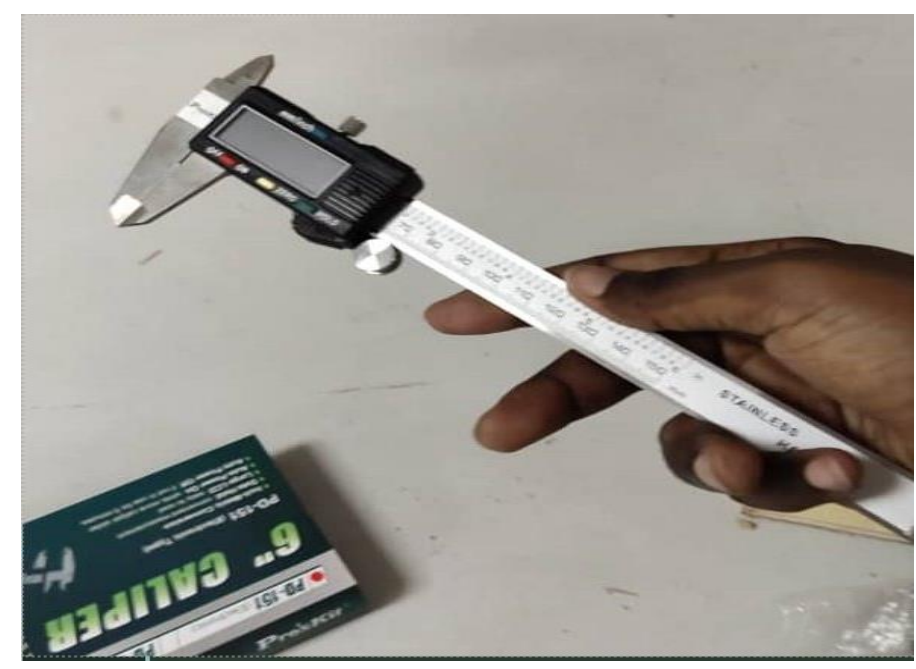

Figure 2. Vernier calipers 
The root systems of the root sample of the Vetiver Grass were obtained by the use of a straight edge for the length of the root and the use of a Vernier Calipers for the diameter of the root. The root morphology of the Vetiver Grass can be determined using the naked eye, as the roots will form in its natural 3 types of root morphology. The samples taken for the primary root and secondary root diameter are provided in Table 4 after thorough measurement with a Vernier Calipers and the length of the root thorough measurement was taken with much accuracy with a straight edge to obtain the measurement. The length of the roots of Vetiver Grass can range from $15 \mathrm{~cm}$ to $33 \mathrm{~cm}$ as reported in the Table 4 . The roots diameters are very small and mostly for all primary roots the diameter is in the $0.7 \mathrm{~mm}-0.8 \mathrm{~mm}$ range. For the diameters of the secondary roots of the Vetiver Grass as reported in Table 4, the root diameter ranges in between about $0.5 \mathrm{~mm}-0.59 \mathrm{~mm}$.

\subsection{Shear Box Test with Root and without Root}

The shear box test was conducted according to the ASTM D 3080 - Standard Test Method for Direct Shear Test of Soils Under Consolidated Drained Conditions. This experiment determined the shear strength of the soil for both soils with and without roots as in Table $\mathbf{5}$ and Table $\mathbf{6}$. The results for the two conditions were analyzed.

Table 5. Summary of Shear Box Test without root

\begin{tabular}{|c|c|c|c|c|c|}
\hline Sample & $\begin{array}{c}\text { Normal } \\
\text { Stress } \\
\left(\mathrm{kN} / \mathrm{m}^{2}\right)\end{array}$ & Loading (kg) & $\begin{array}{c}\text { cohesion } \\
\left(\mathrm{kN} / \mathrm{m}^{2}\right)\end{array}$ & $\begin{array}{c}\text { Angle of } \\
\text { Friction }(\phi)\end{array}$ & $\begin{array}{c}\text { Shear } \\
\text { Strength, } \tau \\
\left(\mathrm{kN} / \mathrm{m}^{2}\right)\end{array}$ \\
\hline \multirow{3}{*}{$\begin{array}{l}\text { Soil Karak } \\
(152.9 \mathrm{~km})\end{array}$} & 8.1 & 3 & 50.0 & 81.0 & 42.9 \\
\hline & 16.3 & 6 & 50.0 & 81.0 & 36.7 \\
\hline & 24.5 & 9 & 50.0 & 81.0 & 30.1 \\
\hline \multirow{3}{*}{$\begin{array}{c}\text { Soil } \\
\text { Temerloh } \\
(161.2 \mathrm{~km})\end{array}$} & 8.1 & 3 & 5.0 & 83.0 & 38.8 \\
\hline & 16.3 & 6 & 5.0 & 83.0 & 68.5 \\
\hline & 24.5 & 9 & 5.0 & 83.0 & 100.2 \\
\hline \multirow{3}{*}{$\begin{array}{l}\text { Soil Kuantan } \\
(189.2 \mathrm{~km})\end{array}$} & 8.1 & 3 & 3.9 & 82.9 & 27.6 \\
\hline & 16.3 & 6 & 3.9 & 82.9 & 48.3 \\
\hline & 24.5 & 9 & 3.9 & 82.9 & 70.6 \\
\hline
\end{tabular}


Table 6. Summary of Shear Box Test with root

\begin{tabular}{|c|c|c|c|c|c|}
\hline Sample & $\begin{array}{c}\text { Normal } \\
\text { Stress } \\
\left(\mathbf{k N} / \mathbf{m}^{2}\right) \\
\end{array}$ & Loading (kg) & $\begin{array}{c}\text { cohesion } \\
\left(\mathrm{kN} / \mathrm{m}^{2}\right)\end{array}$ & $\begin{array}{c}\text { Angle of } \\
\text { Friction }(\phi)\end{array}$ & $\begin{array}{c}\text { Shear } \\
\text { Strength, } \tau \\
\left(\mathrm{kN} / \mathrm{m}^{2}\right)\end{array}$ \\
\hline \multirow{3}{*}{$\begin{array}{c}\text { Roots Karak } \\
(152.9 \mathrm{~km})\end{array}$} & 8.1 & 3 & 28.3 & 83.0 & 62.2 \\
\hline & 16.3 & 6 & 28.3 & 83.0 & 91.8 \\
\hline & 24.5 & 9 & 28.3 & 83.0 & 123.5 \\
\hline \multirow{3}{*}{$\begin{array}{c}\text { Roots } \\
\text { Temerloh } \\
(161.2 \mathrm{~km}) \\
\end{array}$} & 8.1 & 3 & 120.5 & 74.4 & 107.8 \\
\hline & 16.3 & 6 & 120.5 & 74.4 & 96.7 \\
\hline & 24.5 & 9 & 120.5 & 74.4 & 84.8 \\
\hline \multirow{3}{*}{$\begin{array}{c}\text { Roots } \\
\text { Kuantan } \\
(189.2 \mathrm{~km})\end{array}$} & 8.1 & 3 & 42.5 & 70.4 & 72.1 \\
\hline & 16.3 & 6 & 42.5 & 70.4 & 98.1 \\
\hline & 24.5 & 9 & 42.5 & 70.4 & 125.9 \\
\hline
\end{tabular}

\subsection{Factor of Safety (FOS)}

Equation 2 was used to calculate Factor of Safety (FOS) for all shear box experiments with the root of Vetiver grass and without the root of Vetiver Grass. Table 7 and Table 8 shows the results of FOS for all samples.

$$
F O S=\frac{\tau}{\tau_{f}}=\frac{\tau}{c+\sigma \tan \theta}
$$

whereby

$\tau=$ Maximum Shear Stress $\left(\mathrm{kN} / \mathrm{m}^{2}\right)$

$\mathrm{c}=$ cohesion $\left(\mathrm{kN} / \mathrm{m}^{2}\right)$

$\theta=$ Internal angle of friction $\left(^{0}\right)$

$\sigma=$ Normal Stress $\left(\mathrm{kN} / \mathrm{m}^{2}\right)$

Fs $=$ Factor of safety 
Table 7. FOS for soil samples taken from Karak, Temerloh and Kuantan

\begin{tabular}{|c|c|c|c|c|c|c|c|}
\hline $\begin{array}{c}\text { Site } \\
\text { Location }\end{array}$ & Samples & $\begin{array}{c}c \\
\left(k \mathbf{N} / \mathbf{m}^{2}\right)\end{array}$ & $\begin{array}{c}\text { Normal } \\
\text { Stress } \\
\left(\mathbf{k N} / \mathbf{m}^{2}\right)\end{array}$ & $\begin{array}{c}\text { Internal } \\
\text { Angle } \\
\left({ }^{0}\right)\end{array}$ & $\begin{array}{c}\text { Max } \\
\text { Shear } \\
\text { Stress } \\
\left(\mathbf{k N} / \mathbf{m}^{2}\right) \\
\end{array}$ & $\begin{array}{c}\text { Shear } \\
\text { Strength } \\
\left(\mathrm{kN} / \mathrm{m}^{2}\right)\end{array}$ & FOS \\
\hline \multirow{3}{*}{ Karak } & \multirow{3}{*}{ Soil } & 28.39 & 8.7 & 83.0 & 85.2 & 62.2 & 1.3 \\
\hline & & 28.39 & 16.3 & 83.0 & 151.1 & 91.8 & 1.6 \\
\hline & & 28.39 & 24.5 & 83.0 & 203.4 & 123. & 1.6 \\
\hline \multirow{3}{*}{ Temerloh } & \multirow{3}{*}{ Soil } & 120.5 & 8.7 & 74.4 & 150.8 & 107.8 & 1.3 \\
\hline & & 120.5 & 16.3 & 74.4 & 183.3 & 96.7 & 1.8 \\
\hline & & 120.5 & 24.5 & 74.4 & 212.5 & 84.8 & 2.5 \\
\hline \multirow{3}{*}{ Kuantan } & \multirow{3}{*}{ Soil } & 42.5 & 8.7 & 70.4 & 76.8 & 72.1 & 1.1 \\
\hline & & 42.5 & 16.3 & 70.4 & 118.4 & 98.1 & 1.2 \\
\hline & & 42.5 & 24.5 & 70.4 & 149.2 & 125.9 & 1.1 \\
\hline
\end{tabular}

Table 8. FOS for soil with root samples taken from Karak, Temerloh and Kuantan

\begin{tabular}{|c|c|c|c|c|c|c|c|}
\hline $\begin{array}{c}\text { Site } \\
\text { Location }\end{array}$ & Samples & $\begin{array}{c}c \\
\left(\mathbf{k N} / \mathbf{m}^{2}\right)\end{array}$ & $\begin{array}{c}\text { Normal } \\
\text { Stress } \\
\left(\mathbf{k N} / \mathbf{m}^{2}\right)\end{array}$ & $\begin{array}{c}\text { Internal } \\
\text { Angle } \\
\left({ }^{0}\right)\end{array}$ & $\begin{array}{c}\text { Max } \\
\text { Shear } \\
\text { Stress } \\
\left(\mathbf{k N} / \mathbf{m}^{2}\right) \\
\end{array}$ & $\begin{array}{c}\text { Shear } \\
\text { Strength } \\
\left(\mathbf{k N} / \mathbf{m}^{2}\right)\end{array}$ & FOS \\
\hline \multirow{3}{*}{ Karak } & \multirow{3}{*}{$\begin{array}{l}\text { Soil and } \\
\text { root }\end{array}$} & 50 & 8.7 & 81.0 & 104.3 & 42.9 & 2.4 \\
\hline & & 50 & 16.3 & 81.0 & 132.4 & 36.7 & 3.6 \\
\hline & & 50 & 24.5 & 81.0 & 205.6 & 30.1 & 6.8 \\
\hline \multirow{3}{*}{ Temerloh } & \multirow{3}{*}{$\begin{array}{c}\text { Soil and } \\
\text { root }\end{array}$} & 5.1 & 8.7 & 83.0 & 103.4 & 38.8 & 2.6 \\
\hline & & 5.1 & 16.3 & 83.0 & 120.3 & 68.5 & 1.7 \\
\hline & & 5.1 & 24.5 & 83.0 & 259.4 & 100.2 & 2.5 \\
\hline \multirow{3}{*}{ Kuantan } & \multirow{3}{*}{$\begin{array}{l}\text { Soil and } \\
\text { root }\end{array}$} & 3.9 & 8.7 & 82.9 & 72.4 & 27.6 & 2.6 \\
\hline & & 3.9 & 16.3 & 82.9 & 145.7 & 48.3 & 3.1 \\
\hline & & 3.9 & 24.5 & 82.9 & 223.5 & 70.6 & 3.2 \\
\hline
\end{tabular}

The factor of safety (FOS) is the key to determine the effect of shear strength of soil with and without root. As the results shown from the shear box test and the calculation of the FOS, the FOS is higher for soil with the roots of Vetiver grass roots rather than having no roots present. 


\section{Conclusion}

It can be concluded that the strength of soil without the presence of the root of Vetiver grass is weaker compared to that of soil with the support of the Vetiver grass root system. The shear strength of soil without roots obtained are ranged from 27.6 to $100.2 \mathrm{kN} / \mathrm{m}^{2}$. While the shear strength of soil with roots obtained are ranged from 62.2 to $125.9 \mathrm{kN} / \mathrm{m}^{2}$. In term of factor of safety (FOS), the values for soil without root obtained are ranged from 1.1 to 2.5. While the values of FOS for soil with roots obtained are ranged from 1.7 to 6.8. The roots of the Vetiver grass are deep and therefore can root itself deep into slopes causing the slope to have a greater shear resistance. This research has proven that having the roots from the Vetiver grass can act as reinforcement which strengthens the slope.

\section{Acknowledgements}

The authors would like thank SEGi University for their support in conducting the research.

\section{References}

Acharya, K.P., Yatabe, R., Bhandary, N.P., \& Dahal, R.K. (2016). Deterministic slope failure hazard assessment in a model catchment and its replication in neighbourhood terrain. Geomatics, Natural Hazards and Risk, 7(1), 156-185.

Chirico, G.B., Borga, M., Tarolli, P., Rigon, R., \& Preti, F. (2013). Role of Vegetation on Slope Stability under Transient Unsaturated Conditions. Procedia Environmental Sciences, 19, 932-941.

Kacimov, A.R., \& Brown, G. (2015). A transient phreatic surface mound, evidenced by a strip of vegetation on an earth dam. Hydrological Sciences Journal, 60(2), 361-378.

Khalilnejad, A., Faisal Hj. Ali, \& Osman, N. (2012). Contribution of the Root to Slope Stability. Geotechnical and Geological Engineering, 30(2), 277-288.

Lee, W.G., \& Hewitt, A. E. (1982). Soil changes associated with development of vegetation on an ultramafic scree, Northwest Otago, New Zealand. Journal of the Royal Society of New Zealand, 12(3), 229-241.

Meunchang, S., Panichsakpatana, S., Ando, S., Yokoyama, T., \&Meunchang, S. (2004). Phylogenetic and physiological characterization of indigenous azospirillum isolates in Thailand. Soil Science and Plant Nutrition, 50(3), 413-421.

Singh, A.K. (2010). Bioengineering techniques of slope stabilization and landslide mitigation. Disaster Prevention and Management: An International Journal (Vol. 19). 